\title{
PENGARUH RETURN ON ASSET, CURRENT RATIO, SIZE DAN GROWTH TERHADAP STRUKTUR MODAL PADA PERUSAHAAN MANUFAKTUR YANG TERDAFTAR DI BURSA EFEK INDONESIA PERIODE 2013 - 2015
}

\author{
Lina $^{1}$, Afriza Amir ${ }^{2}$ \\ ${ }^{1,2}$ Prodi Akuntansi, Fakultas Ekonomi, Universitas Prima Indonesia, Jalan Belanga No. 1 Simp. Ayahanda, \\ Medan, Sumatera Utara, 20118, Indonesia \\ Email : linaoei96@gmail.com
}

\begin{abstract}
This study aims to test and analyze the effect of Return on Asset, Current Ratio, Size and Growth on Capital Structure in manufacturing company listing in Indonesia Stock Exchange in years 2013 - 2015. In this Research there is 151 population of manufacturing company listing in Indonesia Stock Exchange in years 2013 - 2015. The sample of this research amounted to 183 financial reports from 61 manufacturing companies listing in Indonesia Stock Exchange in years 2013 - 2015. The test results which are the research conclusions are Return on Asset and Current Ratio partially shows negative affect and significant toward Capital Structure in manufacturing company listing in Indonesia Stock Exchange in years 2013 - 2015. Size and Growth no affect toward Capital Structure in manufacturing company listing in Indonesia Stock Exchange in years 2013 - 2015.Return on Asset, Current Ratio, Size dan Growth simultaneously showsaffect and significant the Capital Structure in manufacturing company listing in Indonesia Stock Exchange in years 2013 - 2015.
\end{abstract}

Keywords : Return on Asset, Current Ratio, Size, Growth and Capital Structure

\section{PENDAHULUAN}

Perusahaan manufaktur merupakan bisnis yang berfungsi melakukan konversi persediaan baku mentah menjadi barang setengah jadi yang kemudian dilanjutkan menjadi barang jadi yang mengakibatkan peningkatan nilai konsumsi atas barang tersebut. Pertumbuhan perusahaan industri manufaktur berada pada tingkat tertinggi dalam perkembangan perekonomian di Indonesia karena berhubungan langsung dengan daya beli masyarakat pada umumnya dimana tingkat kepercayaan masyarakat terhadap perusahaan Manufaktur ditentukan oleh kinerja perusahaan tersebut. Perusahaan dengan kinerja yang baik akan menghasilkan keuntungan yang dapat dijadikan sebagai laba ditahan untuk keperluan investasi dan sebagai dividen, sehingga sektor manufaktur menjadi menarik untuk diteliti.

\section{TINJAUAN PUSTAKA}

Return on Asset (ROA). Rasio ini mencerminkan seberapa besar pengembalian yang dihasilkan atas pengelolaan aset yang dimiliki (Murhadi, 2013:64). Menurut Hery (2015:228) berikut adalah rumus yang digunakan untuk menghitung hasil pengembalian atas aset :

$$
\text { ROA }=\frac{\text { Laba bersih }}{\text { Total aset }}
$$

Current Ratio (CR). Rasio ini mencerminkan kemampuan perusahaan dalam memenuhi kewajiban jangka pendek (short run solvency) yang akan jatuh tempo dalam 
waktu satu tahun (Murhadi, 2013 : 57). Menurut Hery (2015:180) berikut merupakan rumus untuk menghitung current ratio :

$$
\mathrm{CR}=\frac{\text { Aset lancar }}{\text { Kewajiban lancar }}
$$

Size. Perusahaan yang berukuran besar pada umumnya berada pada posisi stabil (wellestablished) sehingga memiliki kemudahan dalam memperoleh dana tambahan dalam pasar modal dibanding dengan perusahaan yang berukuran kecil sehingga hal ini menyebabkan perusahaan berukuran besar lebih memiliki fleksibilitas (Sartono, 2012:249). Menurut Rodoni dan Ali (2014 : 193) data kontrol umumnya digunakan dalam ukuran perusahaan bertujuan adakah data dari objek yang diteliti memiliki perbedaan karakteristik tertentu. Variabel kontrol umumnya digunakan adalah size dan biasanya size muncul sebagai variabel penjelas dimana Proksi size adalah total aset perusahaan, Sebab aset biasanya bernilai besar dan untuk menghindari bias skala maka besaran aset dikompres. Secara garis besar, proksi size dipakai logaritma (log) atau logaritma natural asset.

$$
\text { Size }=\text { Logaritma natural }(\mathrm{Ln}) \text { asset }
$$

Growth. Menurut Walsh (2012:199), tingkat pertumbuhan perusahaan yang menggunakan dana sendiri dihitung dengan menyatakan laba ditahan sebagai persentase dana pemilik (memakai neraca awal selama periode tertentu). Pertumbuhan yang melampaui tingkat tersebut akan membutuhkan ekuitas ekstra atau akan menyebabkan rasio melemah. Menurut Harahap (2015:309) rasio pertumbuhan (growth) mencerminkan persentase pertumbuhan pos-pos perusahaan dari tahun ke tahun.

$$
\text { Kenaikan penjualan }=\frac{\text { Penjualan tahun ini }- \text { Penjualan tahun lalu }}{\text { Penjualan tahun lalu }}
$$

Pengaruh Return on Asset terhadap Struktur Modal. Perusahaan yang memiliki laba yang stabil sehingga secara stabil dapat memenuhi kewajiban atas pemanfaatan modal asing, sebaliknya perusahaan yang memiliki laba tidak stabil akan menanggung risiko keuangan akibat adanya penggunaan utang yang lebih (Riyanto, 2015:297).

Pengaruh Current Ratio Terhadap Struktur Modal. Menurut Mulyawan (2015:244) risiko yang melekat pada setiap aktiva belum tentu sama. Semakin panjang jangka waktu penggunaannya, semakin besar risikonya.

Pengaruh Size Terhadap Struktur Modal. Menurut Suripto (2015:8) perusahaan yang lebih besar kemungkinan memiliki protofolio pasar yang lebih, karenanya mempunyai kemungkinan kebangkrutan yang lebih kecil. Ukuran perusahaan akan berpengaruh positif terhadap debt level.

Pengaruh Growth Terhadap Struktur Modal. Menurut Kamaludin dan Indriani (2012 : 325) perusahaan dengan pertumbuhan yang tinggi umumnya membutuhkan lebih banyak pembiayaan dengan tujuan ekspansi sehingga sangat disarankan untuk menggunakan sumber modal eksternal, misalnya menerbitkan saham tambahan dan obligasi.

Hipotesis Penelitian. Adapun hipotesis dalam penelitian ini adalah :

$\mathrm{H}_{1} \quad$ Return on Asset berpengaruh terhadap struktur modal.

$\mathrm{H}_{2} \quad$ Current Ratio berpengaruh terhadap struktur modal.

$\mathrm{H}_{3} \quad$ Size berpengaruh terhadap struktur modal.

$\mathrm{H}_{4} \quad$ Growth berpengaruh terhadap struktur modal.

$\mathrm{H}_{5} \quad$ Return on Asset, Current Ratio, Size dan Growth berpengaruh terhadap struktur modal. 


\section{METODE PENELITIAN}

Peneliti menguji pada Perusahaan Manufaktur yang terdaftar dalam Bursa Efek Indonesia Periode 2013 - 2015. Untuk memperoleh data Perusahaan Manufaktur yang Terdaftar dalam Bursa Efek Indonesia Periode 2013 - 2015 (www.idx.co.id). Peneliti menggunakan pendekatan penelitian kuantitatif untuk menguji variabel penelitian ini. Jenis penelitian ini adalah bersifat hubungan kausal. Peneliti menggunakan sifat penelitian eksplanasi untuk menguji variabel yang diteliti untuk mengetahui hubungan masing-masing variabel penelitian ini.

Populasi atas penelitian ini adalah 151 perusahaan Manufaktur yang Terdaftar dalam Bursa Efek Indonesia Periode 2013 - 2015 dengan jumlah sampel adalah 183 laporan keuangan yang diambil dari 61 Perusahaan Manufaktur yang Terdaftar dalam Bursa Efek Indonesia Periode 2013 - 2015. Model regresi dapat dipakai untuk menguji hipotesi setelah model tersebut diuji 4 asumsi klasik yaitu: uji autokorelasi, uji heteroskedastisitas, dan uji multikolinearitas. Model analisis data ini menggunakan analisis regresi berganda.

Uji Asumsi Klasik

Uji Normalitas. Menurut Ghozali (2013:160-164), uji normalitas dilakukan untuk menguji apakah model regresi memiliki distribusi residual error yang normal, dimana teknik yang sering digunakan adalah analisis grafik dan uji statistik.

Uji Multikolinearitas. Menurut Ghozali (2013:105-106), antar variabel independen sebaiknya tidak terdapat korelasi sehingga uji multikolinieritas dilakukan untuk menguji apakah antar variabel independen dalam model regresi terdapat korelasi.

Uji Autokorelasi. Menurut Ghozali (2013:110-111), uji autokorelasi dilakukan untuk menguji apakah terdapat kesalahan pengganggu pada periode $t$ dengan kesalahan pada periode $\mathrm{t}-1$ (sebelumnya) dalam model regresi linear.

Uji Heteroskedastisitas. Menurut Ghozali (2013:139-143), uji heterokedastisitas dilakukan untuk menguji apakah terjadi ketidaksamaan variance dari residual satu pengamatan ke pengamatan yang lain dalam model regresi.

Analisis Regresi Linear Berganda. Penelitian ini menggunakan analisis regresi linear berganda.Model regresi linear berganda yang digunakan adalah sebagai berikut.

$$
\mathrm{Y}=\mathrm{a}+\mathrm{b}_{1} \mathrm{X}_{1}+\mathrm{b}_{2} \mathrm{X}_{2}+\mathrm{b}_{3} \mathrm{X}_{3}+\mathrm{b}_{4} \mathrm{X}_{4}+\mathrm{e}
$$

Keterangan:

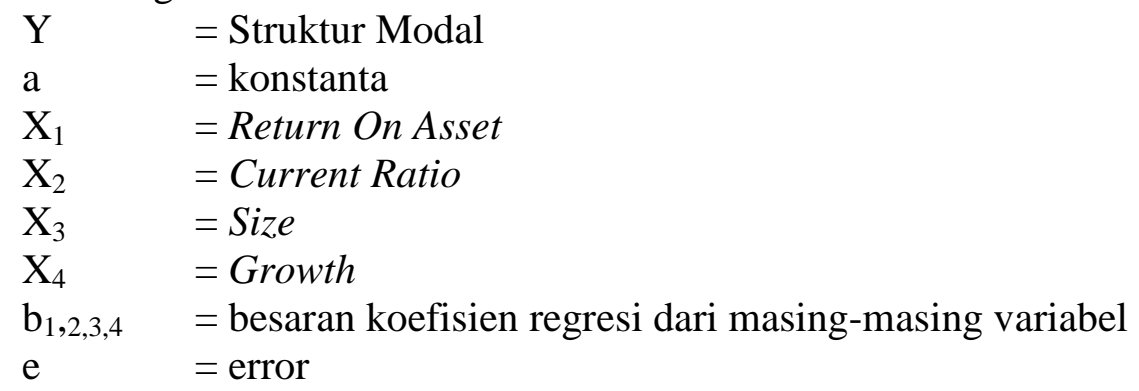

Koefisien Determinasi Hipotesis. Menurut Ghozali (2011:97),koefisien determinasi $\left(\mathrm{R}^{2}\right)$ pada intinya mengukur seberapa jauh kemampuan model dalam menerangkan variasi variabel dependen.

Pengujian Hipotesis Secara Simultan. Menurut Ghozali (2012:97-98), uji F yang signifikan menunjukkan bahwa variasi variabel terikat dijelaskan sekian persen oleh variabel bebas secara bersama-sama adalah benar-benar nyata atau bukan terjadi karena kebetulan.

Pengujian Hipotesis Secara Parsial. Menurut Sanusi (2012:138), uji signifikan terhadap masing-masing variabel bebas terhadap variabel terikat. 


\section{HASIL ANALISIS DAN PEMBAHASAN}

\subsection{Hasil analisis}

Tabel 1 menunjukkan nilai minimum, nilai maksimum, nilai rata-rata (mean), dan standar deviasi dari variabel Return on Asset, Current Ratio, Size, Growth dan Struktur Modal dengan rincian sebagai berikut:

1. Variabel Return on Asset memiliki jumlah sampel sebanyak 183, dengan nilai minimum 0,00 dan nilai maksimum 1,58 sedangkan nilai rata-rata (mean) 0,1097 dengan standar deviasi 0,17718 .

2. Variabel Current Ratio memiliki jumlah sampel sebanyak 183, dengan nilai minimum 0,00 dan nilai maksimum 17,22 sedangkan nilai rata-rata (mean) 2,3214 dengan standar deviasi 1,80963 .

3. Variabel Size memiliki jumlah sampel sebanyak 183, dengan nilai minimum 25,62 dan nilai maksimum 33,13 sedangkan nilai rata-rata (mean) 28,7170 dengan standar deviasi 1,67034 .

4. Variabel Growth memiliki jumlah sampel sebanyak 183, dengan nilai minimum -0,39 dan nilai maksimum 22,48 sedangkan nilai rata-rata (mean) 0,2635 dengan standar deviasi 1,68354 .

5. Variabel Struktur Modal memiliki jumlah sampel sebanyak 183, dengan nilai minimum 0,16 dan nilai maksimum 6,34 sedangkan nilai rata-rata (mean) 1,0014 dengan standar deviasi 0,83448 .

Tabel 1. Statistik Deskriptif

\begin{tabular}{lrrrrr}
\hline & N & Minimum & Maximum & \multicolumn{1}{c}{ Mean } & Std. Deviation \\
\hline ROA & 183 & 0,00 & 1,58 & 0,1097 & 0,17718 \\
CR & 183 & 0,00 & 17,22 & 2,3214 & 1,80963 \\
SIZE & 183 & 25,62 & 33,13 & 28,7170 & 1,67034 \\
GROWTH & 183 & $-0,39$ & 22,48 & 0,2635 & 1,68354 \\
DER & 183 & 0,16 & 6,34 & 1,0014 & 0,83448 \\
Valid N (listwise) & 183 & & & & \\
\hline
\end{tabular}

Sumber : Data olah, 2018

Hasil Uji Asumsi Klasik

Uji Normalitas. Gambar 1 menunjukkan bahwa data residual berdistribusi normal karena dapat dilihat dari arah histogram yang tidak miring ke kanan maupun ke kiri dan membentuk lonceng terbalik.

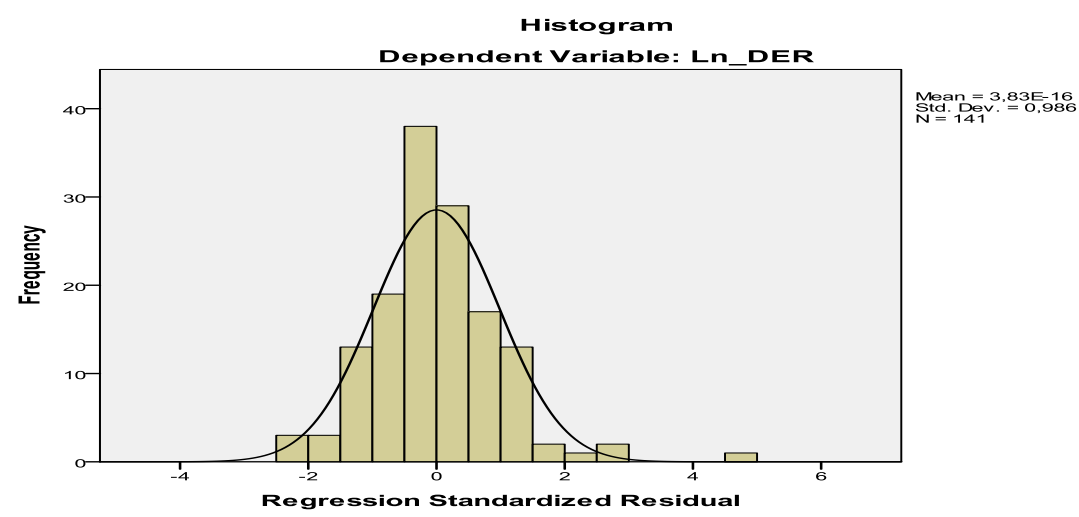

Gambar 1. Uji normalitas histogram setelah transformasi

Gambar 2 menunjukkan bahwa normal probability plot terlihat titik-titik menyebar disekitar garis diagonal, dan mengikuti arah garis diagonal sehingga data berdistribusi normal. 


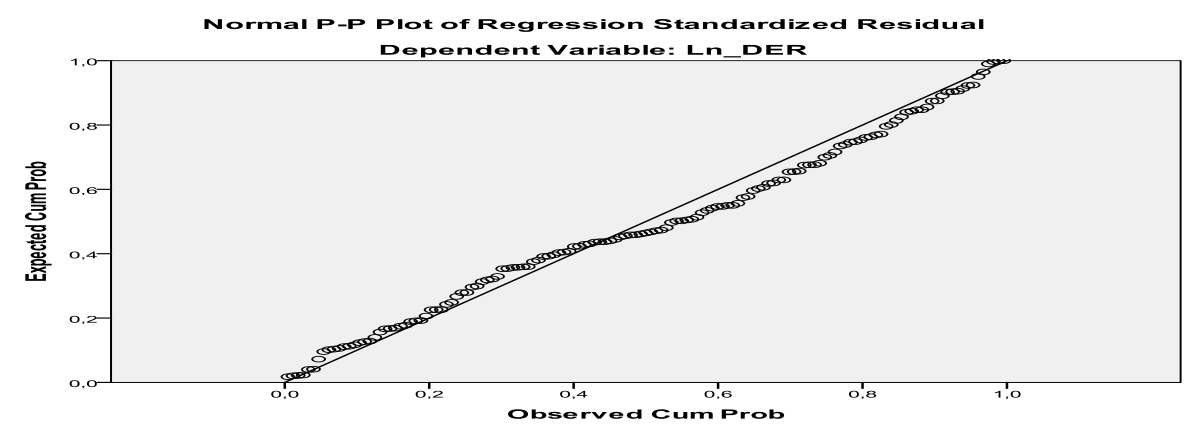

Gambar 2. Uji normalitas P-P Plot setelah transformasi

Tabel 2 menunjukkan bahwa, hasil uji normalitas dengan menggunakan statistik Kolmogorov-Smirnov di atas, dapat diketahui bahwa variabel Return on Asset, Current Ratio, Size, Growth dan Struktur Modalsudah memenuhi syarat distribusi normal karena nilai sig $0,426>0,05$ sehingga data tersebut normal..

Tabel 2. Uji Normalitas Kolmogorov Smirnov Setelah Transformasi

\begin{tabular}{llr}
\hline & & Unstandardized Residual \\
\hline Normal Parameters & & 141 \\
& & 0,0000000 \\
Most Extreme Differences & Mean & 0,49208081 \\
& Std. Deviation & 0,074 \\
& Absolute & 0,074 \\
& Positive & $-0,053$ \\
Kolmogorov-Smirnov Z & Negative & 0,876 \\
Asymp. Sig. (2-tailed) & & 0,426 \\
\hline
\end{tabular}

a. Test distribution is Normal.

b. Calculated from data.

Sumber : Data olah, 2018

Uji Multikolinearitas. Tabel 3 menunjukkan bahwa nilai tolerance variabel Return on Asset, Current Ratio, Size dan Growthdengan perincian nilai tolerance masing-masing variabel 0,850; 0,845; 0,965; 0,934 lebih besar dari 0,10 makadisimpulkan bahwa tidak terjadi multikolinearitas. Nilai VIF yang diperoleh untuk variabel Return on Asset, Current Ratio, Size dan Growthdengan perincian nilai tolerance masing-masing variabel 1,177; 1,184; 1,036; 1,071 lebih kecil 10. Jadi dapat disimpulkan bahwa tidak terjadi multikolinearitas antar variabel independen dalam model regresi tersebut.

Tabel 3. Uji multikolinearitas setelah transformasi

\begin{tabular}{|c|c|c|c|}
\hline & \multirow[b]{2}{*}{ Model } & \multicolumn{2}{|c|}{ Collinearity Statistics } \\
\hline & & Tolerance & VIF \\
\hline \multirow[t]{5}{*}{1} & (Constant) & & \\
\hline & Ln_ROA & 0,850 & 1,177 \\
\hline & Ln_CR & 0,845 & 1,184 \\
\hline & Ln_SIZE & 0,965 & 1,036 \\
\hline & Ln_GROWTH & 0,934 & 1,071 \\
\hline
\end{tabular}

Sumber : Data olah, 2018 
Uji Autokorelasi. Tabel 4 menunjukkan bahwa nilai DW yang diperoleh sebesar 1,844. Cara pengukuran uji autokorelasi adalah $\mathrm{du}<\mathrm{dw}<4-\mathrm{du}$. Nilai dl dan du dalam penelitian ini dengan menggunakan jumlah 4 variabel dan sampel penelitian sebanyak 183 maka nilai $\mathrm{dl}=$ 1.6561 dan nilai $\mathrm{du}=1.8621$. Hasil pengukurannya adalah $\mathrm{du}<\mathrm{dw}<4-$ du maka $1.8621<$ $1,844<(4-1.8621)$ sehingga $1.8621<1,844<2,156$ sehingga disimpulkan tidak terjadi autokorelasi dalam penelitian ini.

Tabel 4. Uji autokorelasi setelah transformasi

\begin{tabular}{clrrrr}
\hline Model & R & R Square & $\begin{array}{c}\text { Adjusted R } \\
\text { Square }\end{array}$ & $\begin{array}{c}\text { Std. Error of } \\
\text { the Estimate }\end{array}$ & Durbin-Watson \\
\hline 1 & $0,724^{\text {a }}$ & 0,524 & 0,510 & 0,49926 & 1,844 \\
\hline
\end{tabular}

a. Predictors: (Constant), Ln_GROWTH, Ln_ROA, Ln_SIZE, Ln_CR

b. Dependent Variable: Ln_DER

Sumber : Data olah, 2018

Uji Heteroskedastisitas. Gambar 3 menunjukkan bahwa data tersebar secara acak dan tidak membentuk suatu pola tertentu. Data tersebar diatas garis 0 yang menunjukkan tidak terjadi heteroskedastisitas.

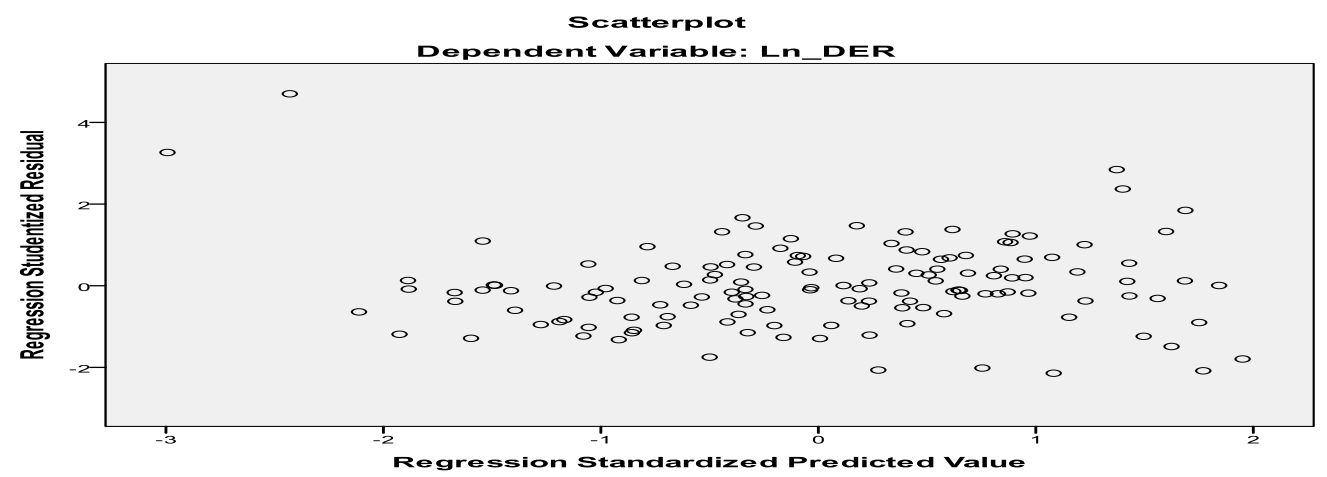

Gambar 3. Uji heteroskedastisitas setelah transformasi

Uji glejser bertujuan untuk meregres nilai absolute residual terhadap variabel indenpenden. Tabel 5 menunjukkan hasil uji dengan menggunakan uji White, dimana nilai R Square adalah sebesar 1,000 dengan perhitungan $\mathrm{c}^{2}$ berikut :

$\mathrm{c}^{2}=\mathrm{n} \times$ nilai $\mathrm{R}$ Square

$=183 \times 1,000$

$=183$

$c^{2}=183>77,93$

Berdasarkan hasil uji white menunjukkan $c^{2}>c^{2}$ tabel maka 183>77,93 tidak terjadi heteroskedastisitas.

Tabel 5. Uji White setelah transformasi

\begin{tabular}{crrrr} 
Model & R & R Square & Adjusted R Square & $\begin{array}{c}\text { Std. Error of the } \\
\text { Estimate }\end{array}$ \\
\hline 1 & $1,000^{\mathrm{a}}$ & 1,000 & 1,000 & 3,70406 \\
\hline
\end{tabular}

a. Predictors: (Constant), GROWTH2, CR2, SIZE2, ROA2

b. Dependent Variable: U2T

Sumber : Data olah, 2018 
Model Penelitian. Pengujian hipotesis yang digunakan dalam penelitian adalah dengan menggunakan analisis regresi linier berganda. Model regresi yang digunakan adalah sebagai berikut :

Ln_DER $=-3,674-0,215$ Ln_ROA - 0,747 Ln_CR + 1,051 Ln_Size + 0,074 Ln_Growth

Hasil interpretasi dari regresi tersebut adalah sebagai berikut:

1. Nilai a sebesar -3,674 artinya jika variabel Return on Asset, Current Ratio, Size dan Growth dianggap konstan, maka Struktur Modaladalah sebesar -3,674.

2. Nilai koefisien Return on Asset $\left(\mathrm{X}_{1}\right)$ adalah -0,215. Ini menggambarkan bahwa setiap kenaikan Return on Asset satu kali maka Struktur Modalakan mengalami penurunan sebesar 0,215 .

3. Nilai koefisien Current Ratio $\left(\mathrm{X}_{2}\right)$ sebesar - 0,747. Ini menggambarkan bahwa setiap kenaikan Current Ratio satu kali maka Struktur Modal akan mengalami penurunan sebesar 0,747 .

4. Nilai koefisien Size $\left(\mathrm{X}_{2}\right)$ sebesar 1,051. Ini menunjukkan bahwa setiap peningkatan Size satu kali maka Struktur Modal akan mengalami peningkatan sebesar 1,051.

5. Nilai koefisien Growth $\left(\mathrm{X}_{2}\right)$ sebesar 0,074. Ini menunjukkan bahwa setiap peningkatan Growth satu kali maka Struktur Modal akan meningkat sebesar 0,074.

Koefisien Determinasi Hipotesis. Tabel 6 menunjukkan bahwa nilai adjusted $R$ Square $\left(\mathrm{R}^{2}\right)$ koefisien determinasi sebesar 0,510 atau sama dengan $51 \%$ dipengaruhi oleh variabel independen terhadap variabel dependen (struktur modal) sedangkan sisanya 49\% dipengaruhi variabel lain seperti seperti stabilitas penjualan, struktur aktiva dan risiko bisnis.

Tabel 6. Uji koefisien determinasi

\begin{tabular}{ccrrr}
\hline Model & R & R Square & Adjusted R Square & Std. Error of the Estimate \\
\hline 1 & $0,724^{\text {a }}$ & 0,524 & 0,510 & 0,49926 \\
\hline
\end{tabular}

a. Predictors: (Constant), Ln_GROWTH, Ln_ROA, Ln_SIZE, Ln_CR

b. Dependent Variable: Ln_DER

Sumber : Data olah, 2018

Pengujian Hipotesis Secara Simultan. Tabel 7 menunjukkan bahwa, hasil $F_{\text {hitung }}$ adalah sebesar 37,388 dengan nilai signifikan 0,000, sedangkan $F_{\text {tabel }}(178)$ adalah sebesar 2,42 maka kesimpulannya adalah $\mathrm{F}_{\text {hitung }}>\mathrm{F}_{\text {tabel }}$ yaitu 37,388 $>$ 2,42 sehingga keputusannya adalah Ho ditolak dan Ha diterima, artinya variabel Return on Asset, Current Ratio, Size dan Growth secara parsial berpengaruh signifikan Terhadap Struktur Modal Perusahaan Manufaktur yang terdaftar dalam Bursa Efek Indonesia Periode 2013 - 2015.

Tabel 7. Uji F

\begin{tabular}{|c|c|c|c|c|c|c|}
\hline & Model & $\begin{array}{l}\text { Sum of } \\
\text { Squares }\end{array}$ & Df & Mean Square & $\mathbf{F}$ & Sig. \\
\hline \multirow[t]{3}{*}{1} & Regression & 37,279 & 4 & 9,320 & 37,388 & $0,000^{\mathrm{a}}$ \\
\hline & Residual & 33,900 & 136 & 0,249 & & \\
\hline & Total & 71,179 & 140 & & & \\
\hline
\end{tabular}

a. Predictors: (Constant), Ln_GROWTH, Ln_ROA, Ln_SIZE, Ln_CR

b. Dependent Variable: Ln_DER

Sumber : Data olah, 2018 
Pengujian Hipotesis Secara Parsial. Tabel 8 menunjukkan hasil pengujian t-test atas pengaruh satu variabel independen terhadap variabel dependen.

Tabel 8. Uji t

\begin{tabular}{|c|c|c|c|c|c|}
\hline \multirow[b]{2}{*}{ Model } & \multicolumn{2}{|c|}{ Unstandardized Coefficients } & $\begin{array}{c}\text { Standardized } \\
\text { Coefficients }\end{array}$ & \multirow[b]{2}{*}{$\mathbf{t}$} & \multirow[b]{2}{*}{ Sig. } \\
\hline & $\mathbf{B}$ & Std. Error & Beta & & \\
\hline 1 (Constant) & $-3,674$ & 2,535 & & $-1,449$ & 0,150 \\
\hline Ln_ROA & $-0,215$ & 0,045 & $-0,305$ & $-4,749$ & 0,000 \\
\hline Ln_CR & $-0,747$ & 0,089 & $-0,543$ & $-8,431$ & 0,000 \\
\hline Ln_SIZE & 1,051 & 0,757 & 0,084 & 1,387 & 0,168 \\
\hline Ln_GROWTH & 0,074 & 0,039 & 0,116 & 1,889 & 0,061 \\
\hline a. Dependent Var & able: Ln DE & & & & \\
\hline
\end{tabular}

Hasil pengujian statistik secara parsial sebagai berikut :

1. Return on Asset mempunyai nilai $t_{\text {hitung }}$ adalah sebesar $-4,749$ dengan nilai signifikan $0,000<0,05$, sedangkan nilai $t_{\text {tabel }}(178)$ adalah sebesar 1,973 sehingga kesimpulannya adalah $-\mathrm{t}_{\text {hitung }}<-\mathrm{t}_{\text {tabel }}$ yaitu $-2,833<-1,973$ maka keputusannya adalah Ho diterima dan $\mathrm{H}_{\mathrm{a}}$ ditolak, artinya variabel Return on Asset secara parsial berpengaruh negatif signifikan Terhadap Struktur Modal Perusahaan Manufaktur yang Terdaftar dalam Bursa Efek Indonesia Periode 2013 - 2015.

2. Variabel Current Ratiomempunyai nilai $t_{\text {hitung }}-8,431$ dengan nilai signifikan $0,000<0,05$, sedangkan $t_{\text {tabel }}$ adalah sebesar 1,973 maka kesimpulannya adalah $-\mathrm{t}_{\text {hitung }}<-\mathrm{t}_{\text {tabel }}$ yaitu $8,431<-1,973$ sehingga keputusannya adalah Ho diterima dan $\mathrm{H}_{\mathrm{a}}$ ditolak, artinya variabel Current Ratio secara parsial berpengaruh negatif signifikan Terhadap Struktur Modal Perusahaan Manufaktur yang Terdaftar dalam Bursa Efek Indonesia Periode 2013 - 2015.

3. Variabel Size mempunyai nilai $t_{\text {hitung }} 1,387$ dengan nilai signifikan $0,168>0,05$, sedangkan $t_{\text {tabel }}$ adalah sebesar 1,973 maka kesimpulannya adalah $t_{\text {hitung }}<t_{\text {tabel }}$ yaitu 1,387 $<$ 1,973 sehingga keputusannya adalah $\mathrm{Ho}$ dan diterima $\mathrm{H}_{\mathrm{a}}$ ditolak, artinya variabel Size tidak berpengaruh Terhadap Struktur Modal Perusahaan Manufaktur yang Terdaftar dalam Bursa Efek Indonesia Periode 2013 - 2015.

4. Variabel Growth mempunyai nilai $\mathrm{t}_{\text {hitung }} 1,889$ dengan nilai signifikan 0,061$\rangle 0,05$, sedangkan $t_{\text {tabel }}$ adalah sebesar 1,973 maka kesimpulannya adalah $t_{\text {hitung }}<t_{\text {tabel }}$ yaitu 1,889 $<$ 1,973 sehingga keputusannya adalah Ho dan diterima $\mathrm{H}_{\mathrm{a}}$ ditolak, artinya variabel Growth tidak berpengaruh Terhadap Struktur Modal Perusahaan Manufaktur yang Terdaftar dalam Bursa Efek Indonesia Periode 2013 - 2015.

\subsection{Pembahasan}

Pengaruh Return on AssetTerhadap Struktur Modal. Return on Asset secara parsial berpengaruh negatif signifikan terhadap struktur Modal Perusahaan Manufaktur yang terdaftar dalam Bursa Efek Indonesia Periode 2013 - 2015.

Pengaruh Current Ratio Terhadap Struktur Modal. Current ratio secara parsial berpengaruh negatif signifikan terhadap struktur Modal Perusahaan Manufaktur yang terdaftar dalam Bursa Efek Indonesia Periode 2013 - 2015.

Pengaruh Size Terhadap Struktur Modal. Size tidak berpengaruh terhadap struktur Modal Perusahaan Manufaktur yang terdaftar dalam Bursa Efek Indonesia Periode 2013 2015.

Pengaruh Growth Terhadap Struktur Modal. Growth tidak berpengaruh terhadap struktur Modal Perusahaan Manufaktur yang terdaftar dalam Bursa Efek Indonesia Periode 2013 2015. 


\section{KESIMPULAN DAN SARAN}

\subsection{Kesimpulan}

Berdasarkan hasil penelitian pada perusahaan manufaktur yang terdaftar dalam Bursa

Efek Indonesia periode 2013 - 2015, maka dapat ditarik beberapa kesimpulan berikut:

1. Return on Asset secara parsial berpengaruh negatif signifikan terhadap struktur modal.

2. Current Ratio secara parsial berpengaruh negatif signifikan terhadap struktur modal.

3. Size tidak berpengaruh terhadap struktur modal.

4. Growth tidak berpengaruh terhadap struktur modal.

5. Return on Asset, Current Ratio, Size dan Growth secara parsial berpengaruh dan signifikan terhadap struktur modal. Nilai koefisien determinasi hipotesis menggunakan $R$ Square sebesar 51\% yang menujukkan bahwa Struktur Modal dapat dijelaskan oleh Return on Asset, Current Ratio, Size dan Growth sebesar 51\%, sedangkan sisanya 49\% dipengaruhi variabel lain seperti seperti stabilitas penjualan, struktur aktiva dan risiko bisnis.

\subsection{Saran}

Berdasarkan hasil penelitian yang telah peneliti kemukakan, saran-saran yang dapat peneliti berikan adalah sebagai berikut:

1. Sebaiknya hasil penelitian ini dapat dijadikan sebagai bahan pertimbangan bagi para investor untuk mengambil keputusan investasi dengan memperhatikan tingkat struktur modal yang ada di perusahaan.

2. Bagi peneliti selanjutnya sebaiknya dapat menggunakan sampelperusahaan yang berasal dari sektor industri lain yang go public di Indonesia,sehingga dapat diperbandingkan dan digeneralisasi dan menjadi bahan referensi bagi peneliti selanjutnya sehubungan dengan pengaruh terhadap struktur modal.

3. Sebaiknya hasil penelitian dapat menjadi tambahan bahan kepustakaan di bidang manajemen keuangan dan pasar modal khususnya pada Universitas Prima Indonesia dan dapat menjadi bahan referensi bagi mahasiswa-mahasiswi lainnya.

\section{DAFTAR PUSTAKA}

Bhawa dan Dewi. 2015. Pengaruh Ukuran Perusahaan, Likuiditas, Profitabilitas dan Risiko Bisnis Terhadap Strutkur Modal Perusahaan Farmasi. E-Jurnal Manajemen Unud, Vol. 4, No. 7, 2015 : 1949-1966. ISSN : 2302-8912.

Fahmi, Irham. 2012. Pengantar Manajemen Keuangan. Bandung : Penerbit Alfabeta.

Fahmi, Irham. 2016. Pengantar Manajemen Keuangan. Bandung : Penerbit Alfabeta.

Ghozali, Imam. 2013. Aplikasi Analisis Multivariate Dengan Program IBM SPSS 21. Jakarta : Penerbit Universitas Diponegoro.

Halim, Abdul. 2015. Manajemen Keuangan Bisnis Konsep dan Aplikasinya. Jakarta : Penerbit Mitra Wacana Media.

Hanafi, Mamduh. 2016. Manajemen Keuangan. Edisi Kedua. Yogyakarta : BPFEYogyakarta.

Harahap, S.S. 2013. Analisis Kritis Atas laporan Keuangan.Jakarta : Penerbit Raja Grafindo Persada.

Herlambang, susatyo dan Marwoto, Bambang Heru. 2014. Pengantar Ilmu Bisnis Cara Mudah Memahami Ilmu Bisnis. Cetakan Pertama. Yogyakarta : Penerbit Parama Publishing.

Hery. 2015. Pengantar Akuntansi Lengkap Dengan Kumpulan Soal Dan Solusinya. Jakarta : Penerbit PT Grasindo.

Hery. 2015. Analisis Laporan Keuangan Pendekatan Rasio Keuangan. Yogyakarta : PT Caps. 
Hery. 2015. Analisis Kinerja Manajemen The Best Financial Analysis Menilai Kinerja Manajemen Berdasarkan Rasio Keuangan. Jakarta : Penerbit PT Grasindo.

Husnan, Suad dan Pudjiastuti, Enny. 2015. Dasar-dasar Manajemen Keuangan. Edisi Ketujuh. Yogyakarta : UPP STIM YKPN.

Ichwan dan Widyawati. 2015. Pengaruh Ukuran Perusahaan, Struktur Aktiva dan Profitabilitas Terhadap Struktur Modal. Jurnal Ilmu \& Riset Akuntansi. Vol. 4 Mo. 6 (2015).

Jumingan. 2014. Analisis Laporan Keuangan. Jakarta: PT Bumi Aksara

Kamaludin \& Rini Indriani. 2012. Manajemen Keuangan. Bandung : Penerbit CV. Mandar Maju.

Kasmir. 2011. Analisis Laporan Keuangan. Cetakan Keempat. Jakarta : Penerbit Rajagrafindo Persada.

Kasmir. 2013. Pengantar Manajemen Keuangan, Edisi Revisi. Jakarta: Prenada Media.

Krsitian dan Khuzaini. 2014. Pengaruh Likuiditas dan Profitabilitas Terhadap Struktur Modal dan Rasio Aktivitas Sebagai Intervening. Jurnal \& Riset Manajemen. Vol. 3 No. 12 (2014).

Mulyawan, Setia. 2015. Manajemen Keuangan. Bandung : Penerbit CV Pustaka Setia.

Murhadi. 2013. Analisis Laporan Keuangan Proyeksi dan Evaluasi Saham. Jakarta : Penerbit Salemba Empat.

Putri. 2012. Pengaruh Profitabilitas, Struktur Aktiva dan Ukuran Perusahaan Terhadap Struktur Modal Perusahaan Manufaktur Sektor Industri Makanan dan Minuman yang Terdaftar dalam Bursa Efek Indonesia (BEI). Jurnal Manajemen. Volume 01, Nomor 01, September 2012.

Riyanto, Bambang. 2015. Dasar-dasar Pembelanjaan Perusahaan. Edisi Keempat. Cetakan Kelima Belas. Yogyakarta : Penerbit BPFE Yogyakarta

Rodoni, Ahmad \& Ali, Herni. 2014. Manajemen Keuangan Modern. Jakarta : Penerbit Mitra Wacana Media

Sanusi, Anwar. 2012. Metodologi Penelitian Bisnis. Cetakan Ketiga. Jakarta : Penerbit Salemba Empat.

Sartono, Agus.2012. Manajemen Keuangan Teori dan Aplikasi. Yogyakarta : Penerbit BPFE Yogyakarta

Sawir, Agnes. 2015. Analisis Kinerja Keuangan dan Perencanaan Keuangan Perusahaan. Jakarta : PT Gramedia Pustakan Utama

Sitanggang, J.P. 2012. Manajemen Keuangan Perusahaan. Jakarta :Mitra Wacana Media.

Sitanggang, J.P. 2013. Manajemen Keuangan Perusahaan Lanjutan. Jakarta : Penerbit Mitra Wacana Media

Sugiyono. 2012. Metode Penelitian Manajemen. Jakarta : Penerbit CV Alfabeta.

Sujarweni, V.Wiratna. 2014. Metodologi Penelitian Lengkap, Praktis, dan Mudah Dipahami. Cetakan Pertama. Yogyakarta : PT Pustaka Baru

Sunyoto, Danang. 2013. Metodologi Penelitian Akuntansi. Bandung : Penerbit PT Refika Aditama.

Suripto. 2015. Manajemen Keuangan Strategi Penciptaan Nilai Perusahaan Melalui Pendekatan Economic Value Added. Jakarta : Penerbit Graha Ilmu.

Suweta dan Dewi. 2016. Pengaruh Pertumbuhan Penjualan, Struktur Aktiva dan Pertumbuhan Aktiva Terhadap Struktur Modal. E-Jurnal Manajemen Unud, Vol. 5, No. 8, 2016 : 5177-5199. ISSN : 2302-8912.

Wahyudiono. 2014. Mudah Membaca Laporan Keuangan. Jakarta Timur : Perum Bukit Permai.

Walsh, Ciaran. 2012. Key Management Ratio. Edisi Keempat. Jakarta : Penerbit Erlangga Group 